\title{
Improving Teachers' Classroom Action Research Proposal Preparation through Academic Supervision FGD Technique
}

\author{
Budi Syawal Bancin \\ Universitas Negeri Medan \\ Medan, Indonesia \\ syawalbancin04@gmail.com
}

\author{
Darwin \\ Universitas Negeri Medan \\ Medan, Indonesia
}

\author{
Sahat Siagian \\ Universitas Negeri Medan \\ Medan, Indonesia
}

\begin{abstract}
This research is focused on the teachers' ability in doing classroom action research because it would be affected the students achievement during teaching learning process. Thus, this research is aimed to find out the teachers ability in arranging classroom action research proposal through focus group discussion academic supervision technique. This study would be carried out by action research method which was conducted in senior high school. The subjects of the research were 7 teachers who are teaching in Islamic Senior High School (MAN) Karo. Meanwhile, the instrument were used in this research are assessment sheet and observation sheet through 3 steps, they are planning, implementation and follow up. The result of this research showed that the teachers ability in arranging classroom action research was improved from the first cycle to the second cycle. The teachers ability improved from 53.2 to 69.2 . It means the teachers ability improved $14.2 \%$. Thus, it could be concluded that the implementation of academic supervision technique can improve the teachers ability in doing classroom action research in MAN Karo.
\end{abstract}

Keywords: Academic Supervision, Focus Group Discussion

\section{INTRODUCTION}

In developing teacher professionalism, there is a demand for professional teachers as stipulated in the Minister of State Regulation of Administrative Reform and Bureaucratic Reform (Permenneg PAN and RB) Number 16 of 2009 as a refinement to the Decree of the State Minister for Administrative Reform (Kepmenneg PAN) Number 84 of 1993 concerning Position of the Republic of Indonesia The functional teacher and the credit score, the teacher gets a greater chance to be more professional. Teacher demands make it happens through professional development activities which are now referred to as sustainable professional development. Continuing professional development is the development of teacher competencies that are carried out according to needs, gradually, continuously to improve their professionalism.

In this ongoing professional development there are 3 components that must be developed by a teacher, namely selfdevelopment, scientific publications, and innovative work. All three are indicators for a development carried out by professional teachers also in line with the rules for teachers of
Civil Servants / State Civil Servants making scientific papers a form of ongoing guarantee and professional improvement after certification which is confirmed by Permenpan and RB Number 16 of 2009 concerning Teacher Functional Position and Credit Score. and starting in 2013 the Ministry of Education and Culture has implemented a Teacher Performance Assessment (PKG) and Sustainable Professional Development (PKB). Quoted from the regulation of the State Ministry of Administrative Reform and Bureaucratic Reform, (2013) Regulation of the Minister of State Administrative Reform and Bureaucratic Reform No. 16 of 2009 concerning the Functional Position of Teachers and Credit Scores as well as regarding the PKB activities carried out by teachers at each level level can be seen .

In the context of professional development, teachers cannot disengage themselves from academic research activities [1]. Research that is directly related to the main tasks and functions and has a direct impact on improving the quality of learning is classroom action research. In this research activity, the teacher has a strategic role in developing professional competence as well as efforts to improve and improve student learning processes and outcomes.

It was revealed that: (1) action research offers teachers a systematic, collaborative and participatory inquiry process that actively engages teachers with specific issues that are troubling; (2) the action research process equips teachers with the technical expertise and special knowledge needed by teachers to make changes in their professional fields; (3) action research makes teachers more innovative in their professional lives. So the teacher must be able to conduct Classroom Action Research (CAR). In implementing teaching and learning process (PBM) in the classroom, the teacher will find learning problems such as insufficient time allocation for a number of materials that must be delivered, students cannot understand the material well, students who are not focused and so on. To overcome the above problems, professional teachers will take systematic and directed actions until changes and improvements occur. When teachers take action to overcome the problem, in fact at that time the teacher has conducted CAR. Conducting CAR is a teacher's reflective action to improve the quality of learning, which is one of the core competencies in teacher's pedagogical competence. 
Based on a number of the provisions above, various problems arise in fulfilling teacher credit scores that must be met based on the statement of Sulistiyo, Chairperson of the Republic of Indonesia Teachers Association (PGRI) [2]. Correspondingly, based on interviews conducted by researchers in accordance with also with some teachers at the Karo State Madrasah on 30 July 2018 there were 7 teachers who had never made CAR of 9 teachers who taught religion lessons, both due to lack their ability in making CAR is because they have never received training on CAR and some have indeed even attended training on CAR but have never been to make a scientific papers in the form of CAR, and there are also some teachers who do not want to continue their promotion because of the requirements of scientific writing in the credit numbers that must be taken to support the promotion. this shows the compatibility between the above problems with those occurring in the field today that there are still many teachers whose abilities are weak in writing Scientific Papers.

Following up on the teacher's problems in carrying out professional duties, the government made an effort to improve by programming teacher competency development activities. One example of teacher performance improvement activities is through supervisors, people who carry out supervision activities towards teachers [3]. Actions that can be taken to improve the ability of MAN teachers to make CAR Proposals are to hold academic supervision of Madrasah Heads of technical focus group discussions (FGD). Which through academic supervision is expected to improve the ability of teachers.

The problem discussed in this paper is an effort to improve the ability of teachers in compiling CAR through the academic supervision of the Madrasah Head of FGD at MAN Karo.

The ability is something that is owned by someone to carry out the tasks and work assigned to him [4]. Abilities are defined as the salient characteristics of an individual who are associated with effective and/or superior performance in a job or situation [5].

There are two factors that affect ability [6], namely:

1. Intellectual Ability Intellectual ability is the ability needed to perform various mental activities, think, reason and solve problems.

2. Physical Ability Physical ability is the ability of tasks that require stamina, skills, strength and similar characteristics.

In the matter of strengthening the school supervisors of the Director General of the Improvement of the Quality of Educators and Education Personnel of the Ministry of National Education action research is a form of self-reflection research conducted by participants in social situations (including education) for improve self-practicing practices[7].

CAR through a combination of three word definitions namely "Research" + "Action" + "Class". The meaning of each word is as follows. Research; activities examine an object by using certain methods and methodologies to obtain data or information that is useful in solving a problem [8]. Action; something that is deliberately done with a specific purpose. Actions carried out in CAR are in the form of a series of activity cycles. Class; a group of students who, at the same time, receive the same lessons from the same teacher. Students who learn are not only limited in a classroom, but can also when students are doing field trips, lab work in the laboratory, or learning other places under the direction of the teacher.

Before implementing the CAR, the teacher first prepares a research proposal consisting of at least introduction (background of the problem, problem formulation, research objectives, and research benefits). development concepts and theoretical reviews; and research methodology or development methods.

Furthermore the etymological supervision comes from the words "super" and "vision" which means to see and review from above or view and assess from above what is done by superiors on the activities, creativity, and subordinate performance [9]. Based on the definition above, it can be concluded that supervision is an effort by a superior within a company or an organization in evaluating and evaluating the performance of subordinates.

The general objective of supervision is to provide technical assistance and guidance to teachers (and other school staff) so that the personnel are able to improve the quality of their performance, especially in carrying out tasks, namely carrying out the learning process[10]. Furthermore there are 3 objectives of academic supervision, namely: (1) helping teachers develop teaching and learning processes; (2) assisting teachers in translating curriculum into teaching and learning language; (3) assisting teachers in developing school staff [11].

In line with that, that there are several techniques of supervision that are seen or considered useful, namely; (1) Class Visits, (2) Individual Talks, (3) FGD, (4) Teaching Demonstrations, (5) Inter-Teacher Class Visits, (6) Curriculum Development, (7) Supervision Bulletins, (8) Professional Libraries, (9) Workshops, and (10) Community School Surveys [12].

Focus group discussions can consist of 7-10 to 10 people but can be multiplied to a maximum of twelve people. More than twelve members, the group will be ineffective because the guide's attention is too widespread [13]. The steps that need to be considered in the implementation of the FGD include:

1. Determine the time of FGD implementation. FGDs are usually held for 60-120 minutes and can be done several times.

2. Determine the number of FGD participants. There are 710 participants in the group, but there can be up to 12 people.

3. Determine the composition of the FGD group, including social class, life status, skill level, cultural differences, and gender.

4. Determine the location of the FGD discussion. Factors that must be considered in determining the venue for the FGD are, among others, bringing a sense of security, comfort, a neutral environment, and is easily accessible to participants. 
5. Seating arrangements. Seats are arranged so that participants are encouraged to talk.

6. Prepare the facilitator.

The formatter will need to create these components, incorporating the applicable criteria that follow.

\section{METHOD}

This research was carried out in the MAN Karo District. Samura gg. Madrasah no.6 Kabanjahe The research subjects are teachers in MAN who are directly involved in teaching and learning activities on Islamic education (PAI) subjects totaling 7 people.

The models used in this action research are Kemmis and Tagart Models designed with a cycle process (cylical) consisting of 4 (four) phases of activity namely: planning (planning), taking action (action), observing (observing), and reflecting (reflective). These stages keep repeating until the problem is considered solved.

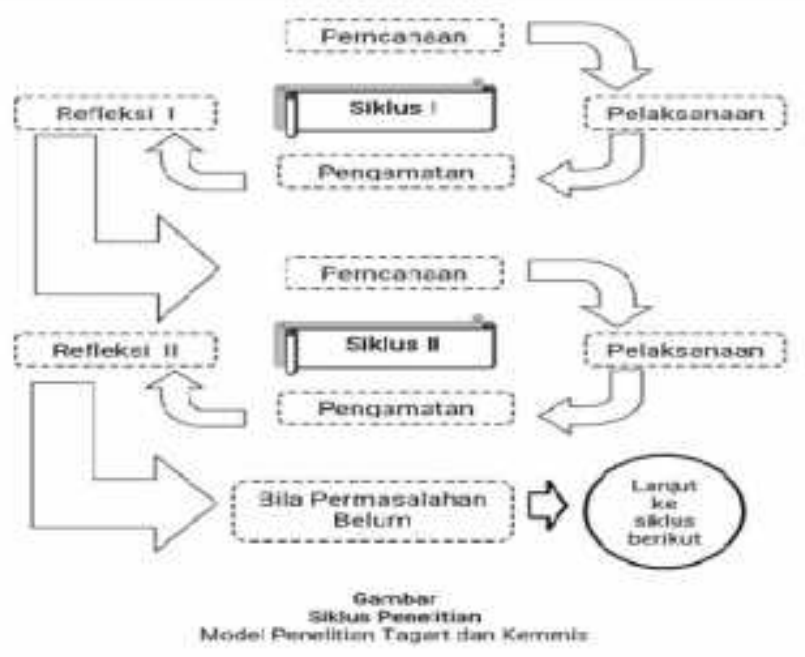

This research was conducted collaboratively between the principal, a supervisor, researcher, teachers, and MAN Karo staff.

Collaboration is realized to equalize understanding, agreement on issues, decision making and giving birth to similar actions aimed at improving the ability of teachers in developing CAR proposals.

In carrying out research, school actions must refer to research designs that have been designed in accordance with applicable research procedures. Its function is as a benchmark to find out the ability of teachers in preparing the CAR proposals through group supervision techniques.

\section{RESULTS AND DISCUSSION}

Based on the Pre-Cycle results in this study based on 10 assessment descriptors with 1 descriptor has 4 points, thus the overall maximum score is 40 so it can be seen that the total score obtained by the teacher in preparing the proposal prior to the focus of technical academic supervision FGD (Cycle I). The total value obtained 372.5 with an average value of 53.2 with very poor categories. From the table it was also found that there were two (2) teachers who received a score of 24 with a value of 60, two (2) teachers who received a score of 22 with a value of 55, one (1) teacher who received a score of 20 with a value of 50 , one (1) the teacher gets a score of 19 with a value of 47.5 , and one (1) the teacher gets a score of 18 with a value of 45 .

Based on completeness criteria, a teacher completes or capable in preparing CAR proposals if the teacher is able to get a value $\geq 80$. To measure the teacher's ability to prepare CAR proposals, the following formula is used:

Value $=\frac{\text { Score obtained }}{\text { Total score }} \times 100$

For example to calculate the ability of the teacher "G1" is as follows:

$$
\begin{aligned}
& \text { Value }=\frac{\text { Score obtained }}{\text { Total score }} \times 100 \\
& \text { Value }=\frac{22}{40} \times 100
\end{aligned}
$$

\section{Teacher Completeness $=55$}

So the completeness value "G1" is 55. For the next teacher-name is calculated based on the formula above. The teacher is declared complete if all teachers have an average grade of 80 .

The results of the overall score analysis showed that the ability of teachers to prepare CAR proposals in MAN Karo was still low and included in the poor category with a percentage of $53.2 \%$. The results of the percentage of teachers' ability to prepare the proposals can be illustrated in Table 1.

TABLE 1 RECAPITULATION OF PRE-CYCLE VALUES OF TEACHERS ABILITY TO PREPARE CAR PROPOSAL

\begin{tabular}{|c|c|c|c|}
\hline Value & $\begin{array}{c}\text { Total Number } \\
\text { of Teachers }\end{array}$ & $\begin{array}{c}\text { Percentage } \\
\text { of Teachers }\end{array}$ & Category \\
\hline $0-59$ & 5 & 71,4 & (Very Bad) \\
\hline $60-69$ & 2 & 28,5 & (Bad) \\
\hline $70-79$ & 0 & 0 & (Fair) \\
\hline $80-89$ & 0 & 0 & (Good) \\
\hline $90-100$ & 0 & 0 & (Very Good) \\
\hline Total & 7 & 100 & \\
\hline
\end{tabular}

Based on the implementation of Cycle I in this study through the stages of planning, observation, and implementation of academic supervision activities focus group discussion FGD known number of values obtained was 485 and the average value was 69.2 with the highest value of 80 , and the lowest value of 60 . From the table It is known that there is one (1) teacher who gets a score of 30 with a value of 75 , and one (2) teachers who get a score of 28 with a value of 70 , and one (1) teacher gets a score of 27 with a value of 67.5 , and one (1) the teacher gets a score of 25 with a value of 62.5 , 
and one (1) the teacher gets a score of 24 with a value of 60 , and one (1) the teacher gets a score of 32 with a value of 80 . For a more clear description of the teacher's value in compiling proposal in Cycle I can be seen in Table 2.

TABLE 2 RECAPITULATION OF CYCLE I VALUES OF TEACHERS' ABILITY TO PREPARE CAR PROPOSAL

\begin{tabular}{|l|c|c|l|}
\hline Value & $\begin{array}{c}\text { Total } \\
\text { Number of } \\
\text { Teachers }\end{array}$ & $\begin{array}{c}\text { Percentage } \\
\text { of Teachers }\end{array}$ & Category \\
\hline $0-59$ & 0 & 0 & (Very Bad) \\
\hline $60-69$ & 3 & 42,9 & $($ Bad) \\
\hline $70-79$ & 3 & 42,9 & (Fair) \\
\hline $80-89$ & 1 & 14,2 & (Good) \\
\hline $90-100$ & 0 & 0 & (Very Good) \\
\hline Total & 7 & 100 & \\
\hline
\end{tabular}

Based on table 2 it can be seen that from the recapitulation of the value of the ability of teachers in preparing class action research proposals (CAR) in the first cycle found teachers $(0 \%)$ who have very less value, two (3) teachers $(42.9 \%)$ who have poor grades, two (3) teachers (42.9\%) who have sufficient grades, one (1) teachers $(14.2 \%)$ who have good grades, and no teachers $(0 \%)$ have excellent grades . Thus it can be concluded that the teacher's ability to compile class action research proposals (CAR) after the academic supervision of the Focus Group Discussion FGD technique in the first cycle is classified as less with an average score of 69.2 .

The results of the assessment of the activities of researchers conducted technical supervision of the Focus Group Discussion FGD technique in improving the ability of teachers in the first cycle, with an average grade of 64.7 and classified in the category of insufficient so that it still had to be improved because indicators were still found from the application of the academic supervision of the Focus Group technique FGD discussions that have not been carried out at the preparatory stage are mainly on: 1) Aspect 3 The FGD leaders are accommodating and try to explore the thoughts / views of the participants from the viewpoints of each element. the implementation phase mainly on: 1) Coordinating and cooperating between FGD Focus Group Discussion team members, Monitoring the progress of activities, Modifying / adjusting the implementation of the Focus Group Discussion FGD, and Identifying issues / problems and results 2) not making notes about the teacher during the academic supervision process FGD Focus Group Discussion techniques take place. Furthermore, indicators were also found at the reporting and follow-up stages, namely: 1) the lack of openness of the researchers discussing the results of observations, especially in the agreed aspects (contracts), 2) The lack of researchers sharing the results of the Focus Group Discussion FGD with related school residents to get input / further feedback 3) the absence of moral encouragement given by researchers to teachers to be able to correct their shortcomings and seek follow-up actions on unresolved issues.
The activities in the second cycle are carried out based on the results of the evaluation in cycle I. The researcher and the madrasa head meet to discuss plans to carry out the academic supervision of the focus group discussion (FGD) in cycle II. Indicators that have not been achieved in cycle I will be improved in cycle II using focus group discussion (FGD) techniques.

Based on the results of the preparation of the teacher's research proposals it is known that the total value obtained is 602.5 and the average value is 86.07 with the highest value of 95 , and the lowest value of 82.5 . From this table, it is known that there are two (2) teachers who score 32 with a score of 82.5 , and three (3) teachers who score 34 with a score of 85 , and one (1) teacher receives a score of 35 with a value of 87 , 5 , and one (1) teacher receives a score of 38 with a score of 95. For a more clear description of the teacher's value in preparing a proposal in cycle II can be seen in Table 3.

TABLE 3 RECAPITULATION OF CYCLE II VALUES OF TEACHERS ABILITY TO PREPARE CAR PROPOSAL

\begin{tabular}{|l|c|c|l|}
\hline \multicolumn{1}{|c|}{ Value } & $\begin{array}{c}\text { Total } \\
\text { Number of } \\
\text { Teachers }\end{array}$ & $\begin{array}{c}\text { Percentage } \\
\text { of Teachers }\end{array}$ & \multicolumn{1}{|c|}{ Category } \\
\hline $0-59$ & 0 & 0 & (Very Bad) \\
\hline $60-69$ & 0 & 0 & (Bad) \\
\hline $70-79$ & 0 & 0 & (Fair) \\
\hline $80-89$ & 6 & 85,7 & (Good) \\
\hline $90-100$ & 1 & 14,3 & (Very Good) \\
\hline Total & 7 & 100 & \\
\hline
\end{tabular}

Based on the above table, it can be seen that from the recapitulation of the teacher's ability to prepare class action research proposals (CAR) in cycle II, it was found that teachers $(0 \%)$ had very poor grades, $(0 \%)$ teachers who had poor grades, $(0 \%)$ who have enough grades, six (6) teachers $(85.7 \%)$ who have good grades, and one (1) teacher $(14.3 \%)$ who has very good grades. Thus it can be concluded that the value of the ability of teachers in preparing class action research proposals (CAR) after the academic supervision of the Focus Group Discussion FGD technique in the second cycle is classified as Good with an average score of 86.7.

The comparison of the results of the teacher's ability to prepare the proposals from the Pre-Cycle, Cycle I and Cycle II can be seen in Table 4.

TABLE 4 COMPARISON OF TEACHER'S ABILITY IN PREPARING CAR PROPOSALS IN PRE-CYCLE DATA, CYCLE I AND CYCLE II

\begin{tabular}{|c|c|c|c|c|}
\hline \multirow{2}{*}{ No } & \multirow{2}{*}{ Name } & \multicolumn{3}{|c|}{ Value } \\
\cline { 3 - 5 } & & Pre-cycle & Cycle I & Cycle II \\
\hline 1 & JS & 55 & 75 & 85 \\
\hline 2 & EY & 55 & 70 & 82.5 \\
\hline 3 & AYS & 60 & 80 & 95 \\
\hline 4 & BHS & 50 & 62.5 & 85 \\
\hline 5 & EE & 60 & 67.5 & 82.5 \\
\hline 6 & BU & 47.5 & 70 & 87.5 \\
\hline 7 & MHH & 45 & 60 & 85 \\
\hline & Total & $\mathbf{3 7 2 . 5}$ & $\mathbf{4 8 5}$ & $\mathbf{6 0 2 . 5}$ \\
\hline & Average & $\mathbf{5 3 . 2}$ & $\mathbf{6 9 . 2}$ & $\mathbf{8 6 . 0 7}$ \\
\hline
\end{tabular}


Table 4 shows the average value of the overall ability of teachers in preparing class action research proposals (CAR) has increased in each cycle. From the preliminary data (prasiklus), the teacher's ability score was quite low, only 53.2 in the very poor category. After the action in the first cycle, it increased to 69.2 , but still in the lack category. After taking action in the second cycle all teachers have met the specified completeness criteria that is $\geq 80$, or the average value of the ability of teachers in preparing class action research proposals (PTK) is at 86.07 and is in the good category.

Based on the results of research in the second cycle, it can be seen that of the 7 teachers all teachers $(100 \%)$ were able to prepare a CAR proposal. This shows that the value of the ability of teachers has far increased. Thus, it can be said that the MAN Karo Teachers have been able to prepare a CAR proposal.

\section{CONCLUSION AND SUGGESTION}

Based on the results of the study, there are several findings in this school action research namely the ability of teachers in preparing a CAR proposal has increased after getting the academic supervision of the FGD from the madrasah headmaster. At the pre-cycle stage the average value is 53.2, Very Bad. This is due to the fact that the teachers have not received maximum guidance and services from supervisors. After the academic action of FGD in the first Cycle by the supervisor based on the results of the overall assessment analysis showed that the average ability of the teacher in preparing a CAR proposal had increased to 69.2 with the category Bad. After observing the lack of application of supervision techniques in the first Cycle the implementation of supervision in the second Cycle was carried out with maximum results obtained in the second Cycle which increased to an average of 86.07 of Good category. In cycle II, all subjects exceeded the established success criteria 80 . It can be concluded that the application of academic supervision of FGD technique can improve the teacher's ability to prepare CAR proposal in Madrasah Aliyah Negeri Karo, Karo district.

It is suggested that teachers always try to improve their ability in learning by always being open to receive input and guidance from superiors either by the principal or supervisor through academic supervision and managerial supervision activities.

\section{REFERENCES}

[1] I. N. Sudiana, "Penelitian Tindakan Kelas", Paper presented in Pelatihan Penyusunan Proposal Tindakan Kelas bagi Guru-Guru Bahasa Indonesia pada tanggal 8 Juli 2013 di SMAN 2 Semarapura, 2013.

[2] S. B. Muslim, Supervisi Pendidikan Meningkatkan Kualitas Profesional Guru, $3^{\text {rd }}$ ed. Bandung: Alfabeta, 2013.

[3] Mukhtar and Iskandar, Orientasi Baru Supervisi Pendidikan, Jakarta: Gaung Persada, 2010.

[4] Kementerian pendidikan Nasional, Pembinaan dan pengembangan Profesi Gruru Buku 5, Pedoman Penilaian Kegiatan Pengembangan Keprofesian Berkelanjutan (PKB). Jakarta: Kemendiknas, 2015.

[5] H. B. Uno, N. Lamatenggo, S. M.A. Koni, Menjadi Peneliti PTK Yang Profesional, Jakarta: Bumi Aksara, (2011.
[6] Peraturan Menteri Negara Pendayagunaan Aparatur Negara dan Reformasi Birokrasi (Permenneg PAN dan RB) Nomor 16 Tahun 2009.

[7] S. Kemmis and R. Mc.Taggart, The Action Researh Reader, Victoria: Deakin University Press, 1988.

[8] S. Arikunto, Prosedur Penelitian Suatu Pendekatan Praktik, Jakarta: Rineka Cipta, 2013.

[9] E. Mulyasa, Penelitian Tindakan Sekolah, Bandung: Remaja Rosdakarya, 2010.

[10] S. Arikunto, Dasar - Dasar Supervisi, Cetakan Pertama, Jakarta: Rineka Cipta, 2006.

[11] S. Sagala, Supervisi Pembelajaran Dalam Profesi Pendidikan, Bandung: Alfabeta, 2010

[12] O. Sutisna, Administrasi Pendidikan Dasar Teoritis untuk Praktek Profesional, Bandung. Angkasa, 1983.

[13] Paramita dan Lusi, Focus Group Discussion Dalam Penelitian Kualitatif, 2013. 